\title{
THE EFFECT OF PREVENTION FOR PEER BULLYING IN SECONDARY SCHOOL
}

Batuhan Mutlu ${ }^{1}$, Şermin Yalın Sapmaz ${ }^{2}$, Beyhan Cengiz Özyurt ${ }^{3}$, İrem Şenel ${ }^{1}$, Elif Metin ${ }^{1}$, Melisa Sargut ${ }^{1}$, Riyadh Saeed $^{1}$, Bengisu Uzel Tanriverdi ${ }^{2}$, Hasan Kandemir ${ }^{2}$, Cevval Ulman ${ }^{4}$

${ }^{1}$ Manisa Celal Bayar University School of Medicine, Manisa, TURKEY

${ }^{2}$ Department of Children and Adolescent Mental Health and Diseases, Manisa Celal Bayar University School of Medicine, Manisa, TURKEY

${ }^{3}$ Department of Public Health, Manisa Celal Bayar University School of Medicine, Manisa, TURKEY

${ }^{4}$ Department of Medical Biochemistry, Manisa Celal Bayar University School of Medicine, Manisa, TURKEY

\section{ABSTRACT}

Aims: Peer bullying is a frequent problem among adolescents. The aim of this study is to evaluate the effectiveness of complementary prevention for peer bullying in 11-14-year-old adolescents with family, teacher, student collaboration and to assess the effect of peer bullying on the quality of life.

Methods: Seven hundred sixty students registered in school between ages 11-14, and who accepted to participate in the study were included in our investigation. Olweus Bully/Victim Questionnaire and Pediatric Quality of Life Inventory were used as data collection tools in the study. After the pre-test, school teachers and two selected students from each class; a total of 48 students were trained in peer bullying in small group. Interactive awareness activities were organized for the students at the school with all trained students and teachers to raise awareness of peer bullying. Afterwards, information brochures were distributed to the children and parents. 3 weeks after the training post-test was applied. The statistical evaluation of the study was carried out by using Chi-square and Student's t-tests.

Results: The questions about bullying and victimization were analyzed. In the study, the rate of victim students reduced from $43.2 \%$ to $30.4 \%$; the rate of bully students reduced from $23.4 \%$ to $21.7 \%$. There was a significant reduction in the rate of people involved in peer bullying. Nevertheless, Pediatric Quality of Life Inventory assessment of health-related quality of life in our group showed that the quality of life of students who were not involved in peer bullying was significantly higher. After our training, quality of life significantly increased in students who were not involved in bullying, compared to the ones who are involved in bullying.

Conclusion: In our study group, it was observed that the quality of life of students who were not involved in peer bullying was significantly higher. The number of people involved in peer bullying decreased significantly. The low number of invalid surveys revealed that our research was successful in attracting the attention of the target group.

Keywords: Awareness, bullying, adolescent

\section{INTRODUCTION}

The 'bullying' behavior can be described as "intentional, repeated long term negative (unpleasant or hurtful) behavior or attitude by one person or a group of people directed against a person having difficulty defending himself or herself" (1). This definition has gained acceptance among researchers and practitioners. Therefore, the phenomenon of bullying can be explained as three separate attitudes: aggressive behavior, carried out repeatedly and over time; intentional "harm doing", carried out repeatedly and over time; an interpersonal relationship that is characterized as an actual, perceived imbalance of power, strength. Therefore, it can be stated; much of the bullying can/ may occur without any apparent provocation from the person being targeted (2). 
In the literature, we see different results for peer bullying. Inequalities in Young People's Health, Health behavior in the school-aged children international report from the 2005/2006 survey indicates that there are large cross-national variations in the proportion, ranging between 4\% (Sweden) to 33\% (Turkey), of youngsters reporting as having been a victim of bullying in their school minimum two or three times in the past months. Currie $\mathrm{C}$ et al. (3) states that boys more often report being a victim of bullying, the experience is reported less often with increasing age.

There are large differences in the extent of reports of bullying others at school at least two times in the past couple of months. While in some countries this behavior is almost nonexistent, it is reported by up to a third in others: 11-year-olds from 2\% (Sweden) to 24\% (Greenland), boys 3\% (Sweden, Czech Republic, Hungary) to 27\% (Greenland, Romania, Estonia), girls 1\% (Norway, Sweden) to 22\% (Greenland). Usually bullying others is more common among boys and decreases with age in most countries (3). Peer bullying is an important determinant of adolescent health-related quality of life (HR-QOL) with a negative impact on psychosocial well-being (4).

As a result, peer bullying causes a negative effect that reduces the quality of human life. Nevertheless, peer violence and quality of life have not been studied together with a holistic education method. The aim of this study is to evaluate the effectiveness of complementary prevention for peer bullying in 11-14-year-old adolescents with family, teacher, student collaboration and to assess the effect of peer bullying on the quality of life.

\section{MATERIAL AND METHODS}

This work is being supported by the European Union Delegation to Turkey Civil Imagine program "International, strengthening the existing child rights network at the national and local level to ensure more be heard children's voices" was funded by the International Children's Center Project. This project financed by Manisa Provincial Directorate of National Education and Governorship has been realized with permission. This study was approved by the ethical committee of Manisa Celal Bayar University of Medical Sciences. The research was conducted on a voluntary basis. Forms were handed out in the classroom. The students filled the forms voluntarily in class, in silence with the teac- her in presence without interrupting.

The study was designed in accordance with the pre-test-post-test method. We applied pre-test before our intervention. Among the first and second surveys, school teachers and two students from each class; a total of 48 students were trained in the definition, types of peer bullying and the best possible reactions that have to be given when experiencing peer bullying. The reason of this training was to create role model peer students for awareness activities of peer bullying from each class. We organized interactive awareness activities, such as icebreaking activities and awareness videos for peer bullying with cake and lemonade, lasting at least 45 minutes were organized for the students at the school with all trained students and teachers to raise awareness of peer bullying. Three weeks after the training and awareness activities, post-test was applied. Information brochures including information about the best possible reactions when experiencing peer bullying were given to the children and parents at the date of the post-test.

Olweus Bully/Victim Questionnaire and the Pediatric Quality of Life Inventory were used as data collection tools in the study. The universe of this research is the students in a secondary school in Manisa $(n=760)$. The sample of the research was 5, 6, 7, 8th-grade Secondary School students aged 11 to 14 who accepted to participate in the study pre-test $(n=603)$, post-test $(n=549)$.

Olweus Bully/Victim Questionnaire includes general or global questions about being bullied in the past months (or bullying other students, in a different section). The students were asked to respond to the questions about all specific forms of bullying. The forms of bullying included in the study are direct physical, verbal, emotional, social harassment and threatening or/and coercive behaviors. In the terms of intentional social isolation, the bullying also includes more indirect or relational ways of harassment, manipulation of friendship relationships and having rumors spread (2). Some questions about digital or cyberbullying are also included (2). Turkish validity and reliability studies were conducted elsewhere (5).

Pediatric Quality of Life Inventory (PedsQl): Examined the reliability and validity of the PedsQl in the assessment of health-related quality of life in pediatric patients (6). There are two different forms as parental scale and self-report. The scale consists of four subdivisions in which physical, emotional, social, and school-related functionality is questioned (6). The increase 
in points, ranging from zero to 100 points, describe the high level of quality of life. In our country, Turkish validity and reliability study of PedsQl was performed for all age groups (7).

The statistical evaluation of the study was carried out using the SPSS 15.0 package program, the responses to pre- and post-tests were compared with Chi-square and Student's t-tests. Numbers, percentages, arithmetic mean \pm standard deviation were used as descriptive statistics. A $p$ value $<0.05$ was set for statistically significance.

\section{RESULTS}

The peer bullying was assessed using the Olweus Bully / Victim Questionnaire, the Turkish translation (6). Questions related to peer bullying were analyzed. As the result of the performed statistical analysis the rate of victim students reduced from $43.2 \%$ to $30.4 \%$; rate of bully students reduced from $23.4 \%$ to $21.7 \%$ in the post-test. There was a reduction of the rate of victims and bullies

\section{Table 1: Answers about bullying and victimization in pre and post tests.}

\begin{tabular}{|c|c|c|c|c|}
\hline \multirow{2}{*}{ Questions } & \multicolumn{2}{|c|}{ Victim } & \multicolumn{2}{c|}{ Bully } \\
\cline { 2 - 5 } & $\begin{array}{c}\text { Pre Test } \\
(\mathrm{n}=592) \%\end{array}$ & $\begin{array}{c}\text { Post Test } \\
(\mathrm{n}=543) \%\end{array}$ & $\begin{array}{c}\text { Pre Test } \\
(\mathrm{n}=586) \%\end{array}$ & $\begin{array}{c}\text { Post Test } \\
(\mathrm{n}=530) \%\end{array}$ \\
\hline $\begin{array}{c}\text { In the past months at school } \\
\text { did not suffer/make peer } \\
\text { bullying }\end{array}$ & 56.8 & 69.6 & 76.6 & 79.3 \\
\hline $\begin{array}{c}\text { It happened only once or twice } \\
\text { It happened 2 or 3 times in a } \\
\text { month }\end{array}$ & 6.3 & 3.1 & 3.1 & 3.8 \\
\hline The average was once a week & 4.4 & 3.3 & 1.9 & 1.9 \\
\hline It happened several times a week & 7.3 & 5.3 & 2.9 & 2.6 \\
\hline
\end{tabular}

in the post-test. However, the decrease of bullying was higher for victim-students than bullies in the post-test. Table 1 shows all answers of the pre and post tests about bullying or victimization.

When peer bullying and gender relations were investigated, it was found out that the difference in terms of peer bullying among gender groups had lost statistical meaning after training (as for pre-test: $\mathrm{p}<0.01$, post-test: $\mathrm{p}>0.05$ ). According to the answers given by the students in the questionnaires on physical, verbal, emotional and cyberbullying in the pre and post-test, gender and the proportions of the victim and bullying students together can be seen in Table 2 .
Table 2: Gender and the proportions of the bullying and victim students in the pre and post tests.

\begin{tabular}{|l|c|l|l|l|}
\hline \multirow{2}{*}{ Items } & \multicolumn{2}{|c|}{ Girls } & \multicolumn{2}{c|}{ Boys } \\
\cline { 2 - 5 } & $\begin{array}{l}\text { Pre Test } \\
\mathrm{n}(\%)\end{array}$ & $\begin{array}{l}\text { Post Test } \\
\mathrm{n}(\%)\end{array}$ & $\begin{array}{l}\text { Pre Test } \\
\mathrm{n}(\%)\end{array}$ & $\begin{array}{l}\text { Post Test } \\
\mathrm{n}(\%)\end{array}$ \\
\hline $\begin{array}{l}\text { That all the questions in } \\
\text { questionnaire indicated students } \\
\text { have not been bullied }\end{array}$ & $85(29.9)$ & $108(41.2)$ & $52(19.1)$ & $95(40.3)$ \\
\hline $\begin{array}{l}\text { At least one of the question in } \\
\text { questionnaire indicates that } \\
\text { students have been bullied at } \\
\text { least once or twice recently }\end{array}$ & $199(70.1)$ & $154(58.8)$ & $220(80.9)$ & $141(59.7)$ \\
\hline $\begin{array}{l}\text { That all the questions in } \\
\text { questionnaire indicated students } \\
\text { have not been bullied others }\end{array}$ & $157(58.4)$ & $180(68.2)$ & $124(47.3)$ & $149(63.9)$ \\
\hline $\begin{array}{l}\text { At least one of the question in } \\
\text { questionnaire indicates that } \\
\text { students have been bullying } \\
\text { others at least once or twice } \\
\text { recently }\end{array}$ & $112(41.6)$ & $84(31.8)$ & $138(52.7)$ & $84(36.1)$ \\
\hline
\end{tabular}

Physical health, emotional functioning, social functioning, and school functioning were analyzed using the PedsQI. Scale total score (STS), physical health total score (PHTS) and psychosocial score (PSTS) were calculated. The results showed that the quality of life of bully or victim-students were significantly lower $(\mathrm{p}<0.001)$. After our training activity, the quality of life scores of students who were not bully or victims were significantly increased $(\mathrm{p}<0.001)$. All results of students who were bullied or victimized are shown in Table 3. Pre and posttests results are shown in Figure 1.

Table 3: Results of pediatric quality of life inventory.

\begin{tabular}{|l|l|c|c|c|}
\hline Variables & & $\begin{array}{l}\text { Physical } \\
\text { health score }\end{array}$ & $\begin{array}{l}\text { Psychosocial } \\
\text { score }\end{array}$ & $\begin{array}{l}\text { Scale total } \\
\text { score }\end{array}$ \\
\cline { 2 - 5 } & & Mean \pm SD & Mean \pm SD & Mean \pm SD \\
\hline Victim & Yes & $82.22 \pm 15.92$ & $78.72 \pm 17.35$ & $80.25 \pm 15.37$ \\
\cline { 2 - 5 } & No & $86.29 \pm 14.22$ & $84.95 \pm 14.45$ & $85.62 \pm 13.25$ \\
\cline { 2 - 5 } & p value & $<0.001$ & $<0.001$ & $<0.001$ \\
\hline \multirow{3}{*}{ Bully } & Yes & $81.90 \pm 16.84$ & $79.51 \pm 17.10$ & $80.70 \pm 15.19$ \\
\cline { 2 - 5 } & No & $85.66 \pm 14.28$ & $83.61 \pm 15.35$ & $84.57 \pm 13.89$ \\
\cline { 2 - 5 } & p value & $<0.001$ & $<0.001$ & $<0.001$ \\
\hline
\end{tabular}

*SD: Standard Deviation

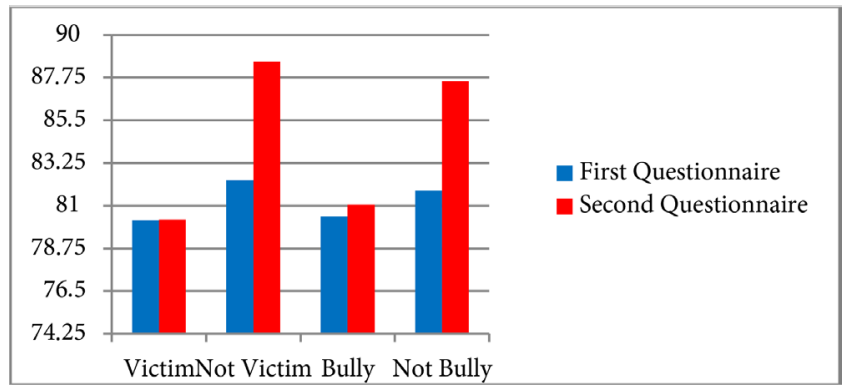

Figure 1: Pre and post test sts score of pediatric quality of life inventory. 


\section{DISCUSSION}

The researchers found that there was an association of bullying with impairment in social role, lower mental health and adverse effects on families which provides additional information and background for peer bullying (4). In our study, there were similar results in different level, we found a relationship between peer bullying and quality of life. It was observed that the quality of life of students who were not included in peer bullying was significantly higher $(\mathrm{p}<0.001)$.

Many governments throughout the world with schools and educators invest money and time for anti-bullying interventions. Generally, these planned interventions showed some decrease in the rate of bullying. The whole-school interventions including complementary components and multiple disciplines directed at different levels of the school organization, more often reduced bullying and victimization rather than the interventions that only includes classroom-level interventions (8). Our pre and post-test assessment coupled with the training of the students and teachers in small groups then the interactive activities in the classroom reduced victimization and bullying in our study. The school based interventions on bullying as a systemic problem usually ends up with a solution. These school based approaches alter the school's entire environment which includes classrooms, teachers, administration, peer groups and individuals in a systematic way. The success of the whole-school interventions remind us that bullying results from external factors directed to individual children's psychosocial problems (9). At our training, we saw that teaching the negative outcomes of peer bullying to bullying students and teaching the basic solutions to victims with interactive classroom activities were successful. In addition, working with teachers, families and school administration was helpful to solve problems.

Peer bullying is a frequent problem among adolescents with different outcomes. The solution to this problem should include multiple variables, such as financial, social, legal and psychological commitments. However, when we consider the high number of students affected and the personal and economic costs of bullying, these efforts are important and necessary (9). In our study setting, students had a variety of different economic, social and cultural status. Cooperating with teachers and administrators in school was important for reaching and changing the school environment; awareness of students and their families, school teac- hers and administrators were improved about peer bullying. We believe this cooperation supported to decrease the problem of peer bullying and increase the quality of children's lives.

Our study shows that the rate of victim students reduced from $43.2 \%$ to $30.4 \%$; rate of bullying students reduced from $23.4 \%$ to $21.7 \%$. There is a reduction in the number of people involved in peer bullying in the post-test which was an effective method for the target group as a whole. It is a limiting factor that the sociodemographic characteristics of students are not examined even if our study has reached the purpose.

Our results show that our training was an effective method for the target group. The low number of invalid surveys reveals that our research is successful in attracting the attention of the target group. To the best of our knowledge, it is the first survey research in our region about peer bullying. The results obtained from this research carried out in one cosmopolitan school for 720 children can give an insight into the big picture. We hope that other researchers will apply similar methods at the national level and our study attracts attention in this field.

Ethics Committee Approval: This study was approved by the ethical committee of Manisa Celal Bayar University of Medical Sciences

Informed Consent: Written informed consent was obtained from the participants of this study.

Conflict of Interest: The authors declared no conflict of interest.

Author contributions: Concept: CU. Design: ŞYS. Supervision: HK, BM. Resources: BM, İ̧, EM, MS, RS. Materials: BM, İ̧̧, EM, MS, RS. Data collection and/or processing: BM, İS, EM, MS, RS. Analysis and/or Interpretation: BÖ. Literature Search: CU, BM. Writing Manuscript: BM. Critical Review: CU.

Financial disclosure: This study was supported by a Project of the Europe an Union Delegation to Turkey 'Strengthening Existing Children's Rights Networks to Act as Children's Voice. 


\section{REFERENCES}

1. Olweus D. Bullying in schools: facts and intervention. Kriminalistik 2010;64(6):351-61.

2. Dan Olweus. School bullying: development and some important challenges. Annu Rev Clin Psychol 2013;9:751-80.

3. Currie C, Gabhainn SN, Godeau E et al. Inequalities in young people's health. HBSC International Report From the 2005/2006 survey, 2008. WHO, Health Policy Children and Adolescents No:5 Available from URL:http://www.euro.who.int/__data/assets/pdf_ file/0005/53852/E91416.pdf.

4. A Wilkins-Shurmer A, O'Callaghan MJ, Najman $\mathrm{JM}$ et al. Association of bullying with adolescent health-related quality of life. J Paediatr Child Health 2003;39(6):436-41.

5. Tıpırdamaz Sipahi H. İzmir ili Bornova ilçesinde ilköğretim 6. ve 7. sınıf öğrencilerinde akran zorbalığı, etkileyen ve eşlik eden faktörler. İzmir: Ege University. 2008.

6. Varni JW, Seid M, Rode CA. The PedsQL: measurement model for the Pediatric Quality of Life Inventory. Med Care 1999;37:126-39.

7. Çakın-Memik, N, Ağaoğlu, B, Coşkun et al. Çocuklar için yaşam kalitesi ölçeğinin 13-18 yaş ergen formunun geçerlik ve güvenilirliği. Türk Psikiyatri Dergisi 2007;18(4):353-63.

8. Vreeman RC, Carroll E. A systematic review of school-based interventions to prevent bullying. Arch Pediatr Adolesc Med 2007;161(1):78-88.

9. Olwus D, Limber SP. The olweus bullying prevention program implementation and evaluation over two decades. In: Jimerson SR, Swearer SM, Espelage DL, editors. The Handbook of Bullying in Schools: An International Perspective. New York: Routledge; 2010. p.377-401. 